\title{
ESTÉTICA Y CRÍTICA DE LA LITERATURA GAUCHESCA (O LA REESCRITURA DE UNA FICCIÓN CULTURAL)
}

\author{
POR \\ TOMÁs Vera Barros \\ Universidad Nacional de Córdoba-CIECS
}

ACLARACIONES PRELIMINARES

¡Perosi Argentina es exactamente al revés; no las lecturas comunes de una tradición, sino una tradición de lectura!

Héctor Libertella, La librería argentina

La "Literatura Gauchesca" es un complejo discursivo; un archivo -discursos y posiciones discursivas, normas, retóricas- con efectos institucionales; una clave de lectura -para lo propio y lo ajeno-; una ficción cultural. En la cultura argentina, el corpus gauchesco es una configuración artificial de una serie de textos de función poética y raigambre política (y viceversa) que ha sido considerado como archivo y clave de lectura, con prístina claridad, desde los más remotos esbozos críticos de la literatura nacional. El primerísimo antólogo y crítico Juan María Gutiérrez señalaba ya en 1871 una forma de leer a la modesta y humilde (ruda, dirá de ella Ricardo Rojas más tarde) poesía gauchesca:

Raro es el acontecimiento político de aquel período [la Revolución de Mayo de 1810] que no se halle consignado en un cielo ${ }^{1}$... contribuía a convertir los espíritus de la gran mayoría del país a los dogmas de la revolución, inculcando en el pueblo aquellas generosas pasiones sin las cuales no hay independencia ni patria (Gutiérrez 41). ${ }^{2}$

Como puede verse en las palabras de Gutiérrez, hay otros fines en juego que el goce estético. La función política de la gauchesca, desde sus orígenes, es motivo y ejercicio de disputa. Ha sido botín de guerra en la literatura y la cultura argentinas: la

\footnotetext{
1 El cielo o cielito es un tipo poético-musical formado por coplas y de circulación y lengua popular. Aunque en los salones de la alta sociedad virreinal y criolla fue practicado como danza, es el canto patriótico revolucionario decimonónico por excelencia.

2 También Rojas, en 1917, advierte la función política de los textos.
} 
lucha y apropiación de este archivo y sus formas de ser leído son parte constituyente de las ficciones culturales de la literatura "nacional". Los románticos y los nacionalistas culturales (Ricardo Rojas), los criollistas (Vicente Quesada) y los nacionalistas (Leopoldo Lugones), David Viñas ("José Hernández, del indio al trabajo y a la conversión”) y Punto de Vista (Número 7, 1979), Martínez Estrada (Muerte y transfiguración de Martín Fierro), Borges (El Martín Fierro) y Leopoldo Marechal ("Simbolismos del Martín Fierro"), los Cuadernos de literatura argentina del CEAL y la Historia Crítica dirigida por Noé Jitrik, entre otros contendientes, ${ }^{3}$ forcejearon para establecer diferentes modos de lectura y de interpretación. En estas pequeñas batallas, la tarea crítica y poética (y crítico-poética) de Leónidas Lamborghini (1927-2009), cuyo alcance no ha sido notado aún, ha sido fundamental: sus técnicas y tópicos líricos tomaron cautiva a la poética gauchesca ${ }^{4}$ para desgranar juicios previos y reabrir el cauce embalsado de esta "tradición", cuya obra culminante, el cierre del ciclo, había sido para la doxa crítica $L a$ vuelta de Martín Fierro [1879].

El concepto de $\operatorname{archivo~}^{5}$ (de una identidad y de una cultura) es una construcción que comparten los propios y que reconocen los otros. Ahora bien: el archivo de discursos, posiciones, normas y retóricas sufre alteraciones cuando es abordado por operadores $^{6}$ (creadores) y críticos (lectores), y esas redefiniciones, desplazamientos o reconfiguraciones alcanzan al concepto mismo de tradición. Las operaciones estéticocríticas de Lamborghini (parodia, grotesco, reescritura, etc.) reordenan el archivo de la literatura gauchesca y, en definitiva, al de la literatura argentina.

Entonces: ¿cuál es el efecto de estos archivos alterados sobre las instituciones?, ¿cómo se construye una/la literatura argentina?, ¿qué variaciones se producen en la literatura argentina cuando se revuelve el archivo? Podemos responder - provisoriamente- que estas operaciones conmueven, en mayor o menor medida, las ficciones culturales -lo nacional, la literatura nacional, la tradición literaria.

También, entre otros: Josefina Ludmer: El género gauchesco. Un tratado sobre la patria; José Pablo Feinmann: Filosofía y Nación; Julio Schvartzman: "Levas y arriadas del lenguaje. El mecanismo proverbial del Martín Fierro", "Las letras del Martín Fierro"; Ángel Núñez: "La heroicidad de Martín Fierro y del pueblo gaucho".

4 La relación con la música y la payada, el tono y los personajes, entre otros.

5 Por "archivo" nos referimos la "constitución de una instancia y de un lugar de autoridad" (Jacques Derrida, "Mal de archivo"); y también, del arkheîon griego, al "derecho y la competencia hermenéuticos" (ibid.).

6 Por operadores nos referimos a una concepción contemporánea del artista; el poeta no ya como creador ex nihilo, ni siquiera como artesano pos-romántico, sino como un operador de materiales ajenos.

Revista Iberoamericana, Vol. LXXXI, Núm. 250, Enero-Marzo 2015, 333-350 ISSN 0034-9631 (Impreso)

ISSN 2154-4794 (Electrónico) 


\section{PERSPECTIVAS: ARCHIVOS, IDENTIDADES E INSTITUCIONES}

Para que los problemas arriba planteados pronuncien respuestas tenemos que considerar procedimientos y juegos discursivos que produzcan y reproduzcan tradiciones intelectuales; específicamente, las disputas por las tradiciones que se testifican en un conjunto de prácticas - el comentario, el ensayo, el paper, la recensión, etc.-e instituciones -la crítica literaria, la universidad, la escuela, etc.

Nos interesa el botín de guerra que es la tradición, objeto privilegiado para reflexionar sobre estas querellas por los significados. "El que escribe pone su marca sobre una tradición, en lo que otros han hecho, aun cuando sea para desajustar el modelo" (Díaz Quiñones 79), tanto vale esta afirmación para las tradiciones literarias como para las tradiciones críticas (escoradas éstas por mareas ideológicas, filosóficas, históricas, generacionales, grupales...).

Román De la Campa ("América Latina") se pregunta si el pasado no es más que "una construcción de malas lecturas". Sin ir tan lejos, digamos que el pasado es una suma de lecturas levemente incorrectas, o incompletas. La historia literaria y la crítica, dos disciplinas canonizantes, también se retroalimentan con equívocos, omisiones, lecturas parciales, juicios cuasi-periodísticos o semi-publicitarios y, últimamente, con vistazos del libro de arena que es Google. Una zona que ha carecido, al menos en las últimas décadas, de rigor analítico; una zona de cruces en la que "en cualquier momento todos terminan cantando en la terraza que es esa arboladura llena de velas del ensayo literario" (Libertella 18).

¿Por dónde comenzar tan ardua tarea? De la Campa propone que los textos literarios subversivos son el archivo en el que buscar "la gramatología de otra posible historia" (“América Latina” 24). La ópera magna de José Hernández es un punto de partida privilegiado para destejer la autoridad y el derecho hermenéuticos dominantes. Justamente, la primera operación cultural de Lamborghini es una relectura del Martín Fierro. Su opera prima, El solicitante descolocado, relee este hito de la gauchesca para refundar una tradición. Y su obra posterior -tanto la crítica como la poética- ha derramado sus ácidos sobre la matriz crítica, modificando el diseño de la gauchesca primitiva y de la epigonal, de la historiografía literaria y de la crítica, del canon y de la academia.

El problema de las diferentes lecturas críticas que se han hecho sobre el archivo de la gauchesca es que no se ajustan a una lectura atenta de las operaciones literarias sino que se centran en y parten de los relatos críticos establecidos y estabilizadores que la comentan y la ordenan. Este problema tal vez obedezca al perfil epistémico de los "nuevos cartógrafos" de la cultura de América Latina. "En EE.UU. y en Canadá, por

Revista Iberoamericana, Vol. LXXXI, Núm. 250, Enero-Marzo 2015, 333-350 ISSN 0034-9631 (Impreso)

ISSN 2154-4794 (Electrónico) 
ejemplo, la formación actual de posgrados en el campo de literatura comparada requiere tanto o más conocimiento de fuentes filosóficas que literarias, y los críticos más leídos han tenido que negociar o reformular su quehacer disciplinario dentro de este espacio híbrido" (De la Campa, "América Latina" 13, énfasis mío). La construcción a-literaria de series y objetos de estudio (los cultural studies), el desgaste epistémico, terminológico y conceptual de las teorías posmodernas, la expansión de la cultura mediática y de la Internet es una problemática-marco (¿una cultura?) en que las formas críticas de leer pierden especificidad, contextualización (histórica, cultural, literaria), precisión y pertinencia. Es decir, es difícil encontrar críticos que hagan un recorrido hacia los adentros de los textos específicamente literarios, que se internen en la profundidad de las series, hasta donde no se vea la huella. Y es raro, a su vez, encontrarse con críticos que desnaturalicen las políticas y las agendas de la crítica.

Los debates el canon, su defensa o su asedio, son acciones de custodia cuando se ejercen desde un centro amurallado de palabras; y son de ataque cuando se realizan desde la periferia hacia ese núcleo de autoridad. El vademecum de textos canónicos va acompañado de un manual de procedimientos para la lectura, incubado por una clase letrada formada en condiciones materiales e intelectuales determinadas y específicas. Pensemos en los modos de leer (verdaderos moldes de lectura) de David Viñas (Contorno y Literatura argentina yrealidad política), BeatrizSarlo(Punto de Vista, Una modernidad periférica...) o Nicolás Rosa (Artefacto, Relatos críticos), por citar sólo tres perspectivas dominantes. Propagación y contagio de formas de estimar y leer la cultura. Por ello, es nuestra responsabilidad como "intelectuales... una capa privilegiada de la sociedad que transmite valores desde las instituciones públicas" (Romano Sued) tener (y hacer) presente la dimensión ética de la constitución de corpora y de las instrucciones de lectura impartidas desde la prensa, en la escuela, en la universidad, etc.

\section{DE LA HISTORIOGRAFÍA Y LA CRÍTICA DE LA GAUCHESCA}

Juan María Gutiérrez, antólogo, crítico y editor primitivo de la literatura de Argentina como literatura "nacional" ("La literatura de Mayo" [1871], 1979), cuando se refiere a los cielitos hace una distinción romántica: una poesía natural, inocente y espontánea. Naturaleza y cultura (alta y baja), deber político y goce social mezclados de distintas maneras en la cultura "argentina" en formación: "la música [del cielito] es al mismo tiempo el lenguaje del corazón del gaucho", que sin embargo "en nuestras más cultas reuniones, [es] la postrera expansión de las satisfacciones de una noche de baile". Para Gutiérrez, este género popular es una forma literaria menor que convive con la alta poesía en la joven cultura nacional: el cielito "se eclipsa delante de la luz llena de la civilización cosmopolita"; este género poético "tan argentino y tan simpático, salió de su oscura esfera desde los primeros días de la revolución". "En cada triunfo patrio se

Revista Iberoamericana, Vol. LXXXI, Núm. 250, Enero-Marzo 2015, 333-350 ISSN 0034-9631 (Impreso)

ISSN 2154-4794 (Electrónico) 
oyeron sus populares armonías a la par de los himnos y de las odas de los grandes poetas" (Gutiérrez 38-40, énfasis mío).

Posteriormente se despliega la enorme labor de Ricardo Rojas, ideólogo inaugural de la literatura argentina como "sistema estético". ${ }^{7}$ Rojas fue el ordenador primero de un corpus canónico vasto y complejo, que no dejó de lado la producción anónima, oral y popular. Lo configuró en series (tomos) individuales e independientes: Los gauchescos [1917], Los coloniales [1918], Los proscriptos [1919] y Los modernos [1922] (eds. princeps, impresa por Coni para Juan Roldán, Buenos Aires). La tarea de Rojas está inspirada por aires hegelianos: "No podría concentrar en estas pocas páginas preliminares la integridad de esa doctrina estética [la literatura argentina como una función de la sociedad argentina], fundada en la evolución de nuestra vida espiritual"; "he procurado descubrir la ley de nuestra ulterior evolución estética" (Rojas 23-24, éngasis agregados). Es más claro aún cuando ilustra su perspectiva crítica con una suerte de anábasis civilizatoria: “... el rumbo de nuestra formación nativa (los gauchescos), el rumbo de nuestra evolución hispanoamericana (los coloniales), el rumbo de nuestra organización democrática (los proscriptos); el rumbo de nuestra renovación cosmopolita (los modernos)" (Rojas 23, énfasis mío). ${ }^{8}$

El haber comenzado su plan de trabajo, publicación y difusión con los gauchescos implica necesariamente el ordenamiento de la "base", de las fundaciones primitivas:" el capítulo primero - "La tierra nativa"- es una suerte de estudio geológico y geográfico, no literario. Puede comprobarse revisando el mismo sumario del primer capítulo: "Anomalías del proceso geológico, Variedad de suelos como consecuencia de sus transgresiones y sus cataclismos, La selva, la cuchilla, el médano, el mar y la montaña como regiones periféricas", etc. ${ }^{10} \mathrm{Al}$ estudiar y sistematizar la gauchesca, no deja de considerarla una producción cultural "de nuestros campos” (Rojas 635), no-urbana... por lo tanto, ¿no civilizada, o bárbara, en la célebre dicotomía sarmientina?: "será destino trascendental de 'los gauchescos', el haber conservado ese prístino aroma de nuestra antigua vida pastoril, en sus ánforas rudas" (Rojas 640). Es decir, una producción cultural exótica más que bárbara, por su higiénica lejanía -tanto espacial como temporal.

Si bien Ricardo Rojas busca sistematizar (también reconozcamos la herencia positivista) y explorar la gauchesca hasta sus orígenes, remontándose a las culturas

"[S]istema crítico que he concebido para estudiar la literatura argentina" (Rojas 23).

8 El subtítulo de su Historia... es "Ensayo filosófico sobre la evolución de la cultura en el Plata".

9 En alguna medida que no ha sido considerada aún, Ricardo Rojas, al comenzar su sistema por las culturas originarias o aborígenes, estaría restañando la "herida colonial" de la que habla Mignolo en diferentes artículos. La opción descolonial supone pensar no desde los griegos como origen de La Civilización, "sino a partir del momento en el que las historias locales del mundo fueron interrumpidas por la historia local de Europa, que se presenta a sí misma como proyecto universal” (Mignolo 16).

10 "La tierra que llamamos Argentina dilátase en el ángulo meridional de nuestra América, desde la zona tropical en donde nacen los largos ríos" (Rojas 69).

Revista Iberoamericana, Vol. LXXXI, Núm. 250, Enero-Marzo 2015, 333-350 ISSN 0034-9631 (Impreso) ISSN 2154-4794 (Electrónico) 
indígenas, apelando a la sociología, a la antropología y a la geografía, no es sino hasta las intervenciones de Ángel Rama que se ha distinguido con claridad lo gaucho de lo gauchesco, la poesía de la literatura, el enunciador del autor, la estética de la pragmática.

Las causas de la literatura gauchesca... no deben buscarse en los asuntos de que trata y menos en los personajes que utiliza, sino en las concretas operaciones literarias que cumplieron los escritores que las produjeron. Lo que implica abandonar uno de esos ilusionismos que construye con sutil artificialidad el verismo -el de que estamos ante espontáneas creaciones del pueblo cantor- y preguntarnos quiénes redactaron estos poemas, por qué y para quiénes los hicieron y qué principios los animaban (Rama, "El sistema literario de la poesía gauchesca", 1977, pág. X).

Si en la introducción a la extensa antología de la Biblioteca Ayacucho ${ }^{11}$ argumenta y marca una línea crítica indeleble en términos de estética, poética y de sociología de la recepción, en Los gauchipoliticos rioplatenses [1976] (1994) su instrumental y su mirada habían sido más duros, más técnicos y de raíz marxista: "el pacto de una ideología moderna con una forma conservadora a través del funcionamiento poético de una lengua, es índice de un nuevo condicionamiento social de las formas literarias en el período de la revolución emancipadora" (Rama, 1994, 42).

Ángel Rama rompe con los análisis nativistas, folcloristas, románticos, nacionalistas y positivistas que poblaron el territorio de la crítica y la historiografía hasta sus intervenciones en los años 70: su posición no es ni peyorativa ni idealizante, ni humorística ni épica, ni se articula en términos de alta cultura versus cultura popular. Su análisis materialista establece condiciones casi definitivas de historización de la gauchesca, al haber incorporado a la ecuación del canon de la literatura nacional el componente político-ideológico y sociológico, sin temor a la condescendencia. "Todos los autores de la gauchesca... pertenecieron a niveles de cultura superiores a los de personajes y ambientes utilizados en sus obras, aunque hay notoria distancia entre [Hidalgo y Ascasubi y Del Campo o Hernández]" (Rama, 1994, 107, énfasis mío).

Las antologías de poesía gauchesca más difundidas y amplias (Rivera y Becco ${ }^{12}$ ) incluyen, entre más o menos autores más o menos reconocidos, las dos partes de $E l$ gaucho Martín Fierro completas. Esta operación consagratoria o canonizadora no es inocente para Rama, y le permite articular a la gauchesca en el orden de su presente histórico y de su instrumental crítico: “...una transformación que se ha operado en la sociedad rioplatense, donde las concepciones de clase afloran al iniciarse la construcción del orden neocolonial... estamos en presencia de una obra representativa [El gaucho

11 Poesía gauchesca, publicada en 1977, Caracas, Biblioteca Ayacucho, 467 páginas. Prólogo de Ángel Rama; selección, notas y cronología de Jorge B. Rivera. Esta edición contó con una amplia circulación.

12 Horacio Jorge Becco, Antología de la poesía gauchesca, Aguilar, Bilbao, 1972, 1777 páginas.

Revista Iberoamericana, Vol. LXXXI, Núm. 250, Enero-Marzo 2015, 333-350 ISSN 0034-9631 (Impreso)

ISSN 2154-4794 (Electrónico) 
Martín Fierro]. Este solo rasgo le confiere una situación privilegiada dentro de la serie literaria gauchesca" (Rama, 1994, 128).

Ángel Rama hace en los 70 una operación de identificación o transferencia crítica: la gauchesca es una poesía revolucionaria, política, partidaria, social. Pero esta maniobra ya estaba anunciada, apropiada, estilizada y utilizada dos décadas antes en la poética germinal de Leónidas Lamborghini. Inicialmente, como un poema fermental: "El saboteador arrepentido" [1955], ampliado y re-titulado como "Al público" [1957] y luego "Las patas en las fuentes" [1965], y finalmente parte del volumen El solicitante descolocado (1971, 2008).

La obra de Lamborghini ha mostrado a lo largo del tiempo su estirpe de heredera, crítica y estilizadora (en términos bajtinianos) de la tradición gauchesca: "Payada" (Partitas, 1972), Circus (1986), Tragedias y parodias (1994) y Risa y tragedia en los poetas gauchescos (2008), entre otros.

En "El saboteador arrepentido" una poesía eminentemente política -la de la proscripción peronista- rescata el aliento social y revolucionario de la gauchesca que décadas más tarde re-conocerá y ordenará Ángel Rama en el discurso crítico. Dicho de otra manera: Lamborghini comprendió en los años 50 la vigencia de la gauchesca como corpus de poesía política que todavía tenía cosas para decir. En términos sociológicos: transforma una estructura residual (la gauchesca) en una estructura del sentir -algo que bulle antes de emerger- apta para articular las voces de los "desheredados" presentes, inmediatos, su "innegable experiencia del presente" (Williams 150). Williams habla de "una experiencia social que todavía se halla en proceso" pero que no es social (precipitada, decantada) sino subjetiva (difuminada). En esta distinción radica el sentido de la operación de Lamborghini sobre la gauchesca: éste utilizó un género agotado, cerrado -lo que Williams llama la cultura en tiempo pasado-, y lo reactivó para pensar una experiencia presente, viva, en proceso, no formalizada. La rehabilitación de la gauchesca a la manera lamborghiniana como un experimento estético en solución (Williams). Dicho de otro modo, Lamborghini encuentra en la gauchesca, elemento residual, potencialidad para aún decir cosas, lo que activa ese elemento y lo hace intervenir en la "solución", lo que retarda su conversión en elemento arcaico.

De la gaUCHESCA y LA ESTÉTICA DEL HARAPO

Estética del harapo: no sólo por su estatuto textual/til -su tejido significante, sus tramas constitutivas-, sino porque también se la ha considerado una pieza artesanal de escaso o rudo arte (Rojas: "rudas ánforas"), un desperdicio, un jirón más que un tapiz:

Tal como en las tapicerías más lujosas se suele descubrir ... la trama de toscos hilos que sustenta las formas historiadas en su arte, así descubrimos hoy ... que los gauchos crearon la trama ... de las dos tradiciones que han elaborado la actual contextura del carácter nativo. Los hilos de esas tradiciones... (Rojas 155).

Revista Iberoamericana, Vol. LXXXI, Núm. 250, Enero-Marzo 2015, 333-350 ISSN 0034-9631 (Impreso)

ISSN 2154-4794 (Electrónico) 
Rojas utiliza una metáfora textil para sistematizar a la gauchesca ("Los doce hilos de la tradición gauchesca" (155 y ss.)), seguramente teniendo presente que la metáfora del narrador y del poeta como tejedor es una figura tan vieja como la literatura misma. ${ }^{13}$

Pero no se trata solamente de la tradición simbólica occidental. El poncho y la vestimenta en general aparecen en la gauchesca con fuerza y pregnancia. Las pilchas indican diferencias de clase, de nacionalidad, de autoridad; pero también marcan la pobreza, el rebusque. Podemos leer en La vuelta del gaucho Martín Fierro [1879]:

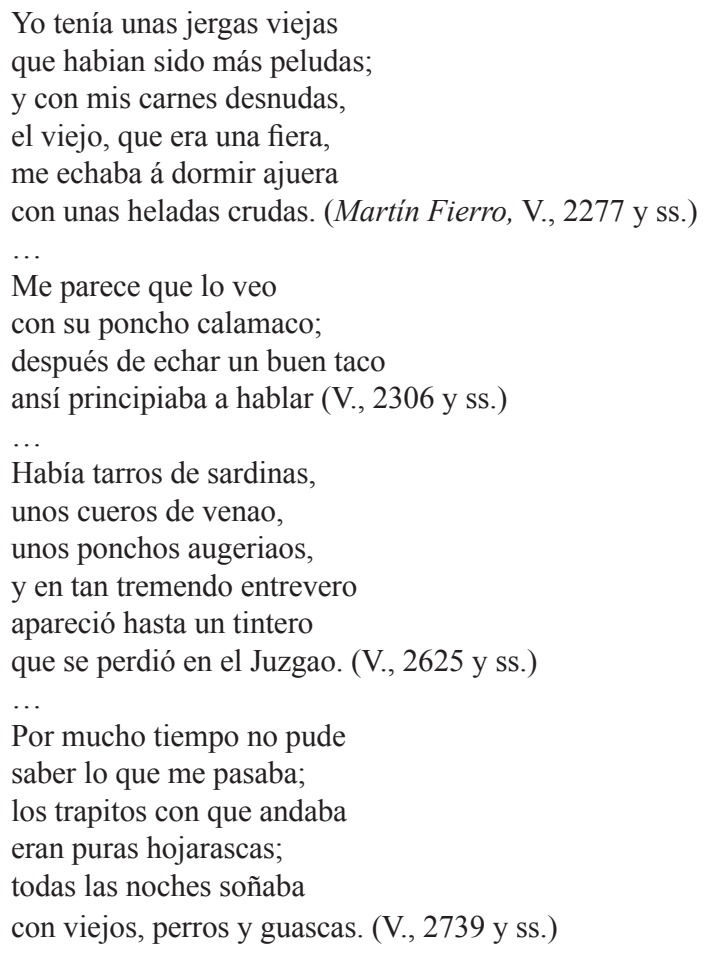

El harapo es representación de un tipo social y es sinécdoque de la pobreza y el desamparo, pero también es una representación de una tecné literaria sin ley, una forajida de la alta cultura. Esta técnica -la de la lengua gauchesca- es una construcción fuertemente estilizada que busca ubicarse en el desierto de la proscripción de la norma

13 Justamente, el narrador/tejedor tiene fuerte presencia en la obra más potente de este "sistema", Martín Fierro: "Y para seguir contando / la historia de mi tutor / le pediré a ese dotor / que en mi inorancia me deje, / pues siempre encuentra el que teje / otro mejor tejedor" (Vuelta, 2475 y ss., énfasis mío).

Revista Iberoamericana, Vol. LXXXI, Núm. 250, Enero-Marzo 2015, 333-350 ISSN 0034-9631 (Impreso)

ISSN 2154-4794 (Electrónico) 
lingüística y estética, como puede comprobarse con el cotejo de las diferentes ediciones y borradores de la composición del Martín Fierro. ${ }^{14}$

Las imágenes y metáforas textiles están en los albores de la literatura argentina, y lo comprendió Ricardo Rojas cuando estudió y sistematizó la gauchesca como una tradición textual/textil. Estas imágenes y motivos son síntoma de los conflictos sociales y políticos llevados a la escritura.

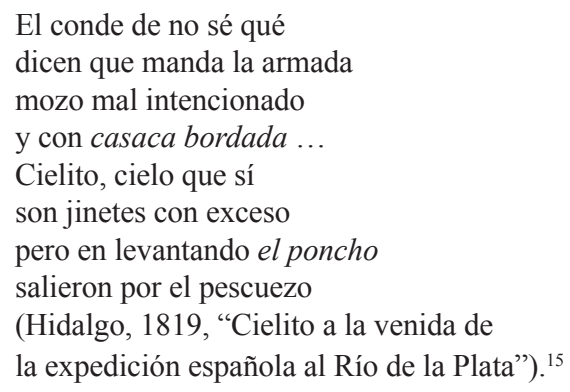

El poncho, elemento distintivo de la cultura criolla (mestiza) y de su sencillez indumentaria se opone a la "casaca bordada" (los tejidos lujosos de Rojas) del invasor español. En Juan Gualberto Godoy (“Confesión histórica”), el yo lírico presenta la misma antinomia gaucho-militar pero invertida, en un registro cercano a la picaresca:

Hijo de un zambo platero
llamado Teodoro Corro,
nací en Salta como un zorro
en un miserable agujero:
vil, ignorante y grosero,
cobarde pero atrevido,
pedi el militar vestido
para cacarear honor... (s/f, circa 1830).

La alfombra es un tercer elemento textil del arriba citado poema de Hidalgo, que marca el deseo de independencia y el temor al poder colonial: "Dicen que esclavas harán / a nuestras americanas, / para que lleven la alfombra a las señoras de España” (Hidalgo, 1819, ibid.). En el "Diálogo patriótico interesante" [1821], un texto que marca un límite a la gauchesca política como polarización nación/imperio, Argentina/España,

\footnotetext{
14 Sobre este particular, ver el interesante artículo de Elida Lois “Cómo se escribió el Martín Fierro" (2003). También, la hipótesis borgeana de "El escritor argentino y la tradición".

15 En adelante, el énfasis es nuestro, salvo se explicite lo contrario.
}

Revista Iberoamericana, Vol. LXXXI, Núm. 250, Enero-Marzo 2015, 333-350 ISSN 0034-9631 (Impreso) 
se presenta en oposición dicotómica al gaucho y a su otro, que ya no es el español de finas prendas, sino el mismo argentino: ciudad/pueblo vs. campo.

[la justicia] nunca hace distinción
de arroyos ni de lagunas
de rico ni pobretón:
para ella es lo mismo el poncho,
que casaca y pantalón ...
sacaban la soldadesca
delgada que era un dolor,
con la ropa hecha miñangos...

La obra del unitario Hilario Ascasubi se distingue, entre otras estrategias, por el uso de la voz del adversario - los federales- para remarcar su crueldad y brutalidad. La inversión o juego de reflejo identitario de hablar con la voz del otro refuerza las polarizaciones que hemos venido comentando. En "La refalosa" (circa 1839): "ya queda codo con codo / y desnudito ante todo... Cuando algunos en camisa se empiezan a revolcar, y a llorar...". En "Paulino Lucero" [1833]:

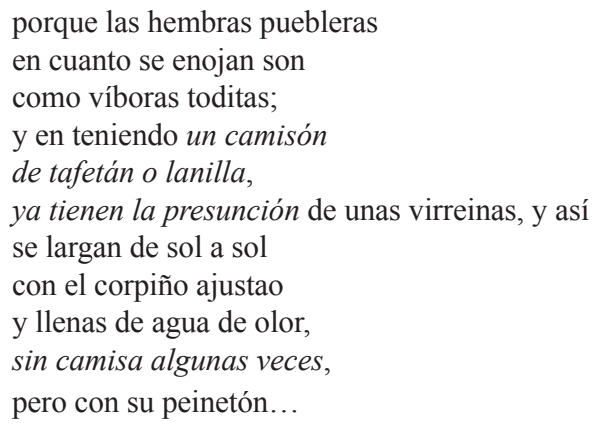

La vestimenta es entonces un código social e identitario cargado de valores y marcado por tensiones. Los vestidos a la europea (arreglos, trajes, bordados) distinguen al español, al unitario y al pueblero del gaucho, el sujeto criollo que condensará la idea de "lo nacional" (para el nacionalismo) y lo "auténtico" (para el nativismo).

En El gaucho Martín Fierro (MF), el gran poema gauchesco, se puede ver de manera clara el esquema de valores relacionado con los arreglos del vestir gaucho. Son pocas las cosas con que cuenta y que valora el gaucho: unas pocas pilchas (poncho, recado, arreos) que funcionan como testigos de la (des)dicha y la (in)justicia. 
andaba despilchao,

no traía una prenda buena;

un recadito cantor

daba fe de sus pobrezas (2920 y ss.)

Y sentao junto al jogón

a esperar que venga el día,

al cimarrón le prendía

hasta ponerse rechoncho,

mientras su china dormía

tapadita con su poncho. (145 y ss.)

Luego comenzó el Alcalde

a registrar cuanto había

[en las pertenecías del viejo Vizcacha],

sacando mil chucherías

y guascas y trapos viejos,

temeridá de trevejos

que para nada servían.

Salieron lazos, cabrestos, coyundas y maniadores, una punta de arriadores, cinchones, maneas, torzales, una porción de bozales y un montón de tiradores. Había riendas de domar, frenos y estribos quebraos; bolas, espuelas, recaos, unas pavas, unas ollas, y un gran manojo de argollas de cinchas que había cortao. (V., 2601 y ss.)

De poco valor son los objetos ratereados y atesorados por el Viejo Vizcacha, acumulado a lo largo de su picaresca historia de vida (V., XIV y ss.).

Si hay una estética creada a partir de la modestia de recursos ("El andar tan despilchado / ningun mérito me quita, MF, 1693-94), es justamente la gauchesca. ${ }^{16}$ Según Gutiérrez, el poeta culto (el letrado), a la hora de componer un cielo, "acomoda y apropia la entonación, las ideas, el lenguaje mismo, al corto alcance de este humilde instrumento [la vihuela]" (Gutiérrez 40). Ángel Rama (1977, XII) coincide: "Todos los gauchescos recalcaron la modestia artística de sus obras... reconociendo de antemano

16 "Las nacientes de nuestra poesía patria son purísimas como las aguas de manantial y [adolece de] todas las inocencias de forma, todas las inexperiencias de estilo que son de esperarse" (Gutiérrez 35). Interesa el juicio de JM Gutiérrez toda vez que es un precedente crítico y un "pedagogo" (cf. Sarlo en Gutiérrez). Dicho más claro: sus palabras son fundamento y cimiento de un canon nacional.

Revista Iberoamericana, Vol. LXXXI, Núm. 250, Enero-Marzo 2015, 333-350 ISSN 0034-9631 (Impreso) 
que no pretendían entrar en competencia con la literatura seria o culta". Esto se da especialmente en la gauchesca partidaria (Eduardo Romano), o gauchipolítica (Ángel Rama), o de circunstancia (que excluye a Del Campo, Lussich y al Ascasubi del Santos Vega [la gauchesca literaria, cf. Romano]). No poco fue el esfuerzo de Hernández para adaptar su escritura elegante y enérgica (ver los textos publicados en el periódico $\mathrm{El}$ Río de la Plata entre 1869 y 1870, transcripción en Lafforgue) al rudo decir gaucho en verso (cf. Lois).

Pero la gauchesca también es un harapo que los sujetos subalternos han utilizado para cubrirse en la intemperie del canon letrado, para protegerse del silencio cultural.

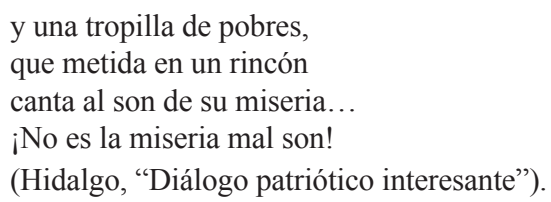

¿Qué gaucho ha hecho oír su voz, si no es a través de un intelectual o letrao, a través de un dotor? Gutiérrez: “....aunque nazca frecuentemente en el corazón de las ciudades y proceda de padres instruidos y cultos..." $(1979,40)$. Rama también lo deja en claro: "los autores de literatura gauchesca no fueron... sino hombres de ciudad con niveles educativos muy variados aunque nunca confundibles con los prototípicos de los gauchos de las pampas” (“El sistema literario de la poesía gauchesca”, 1977, XI).

\section{DE LAMBORGHINI COMO GAUCHESCO: REESCRITURA Y CANON}

La estética del harapo ha presentado una serie de rasgos diferenciales que colaboraron en la creación de un perfil identitario y un sistema de valores para la figura del gaucho (siglos XVIII y XIX). Pero esta estética ha pervivido como mito de origen de un poeta contemporáneo -Leónidas Lamborghini-, que revolvió y deshilachó las pilchas gauchescas para tejer las propias, es decir, para fundar su voz. ${ }^{17}$ El telar, el tejido y el tejedor son metáforas que están en la metapoética gauchesca ("siempre encuentra el que teje / otro mejor tejedor", Martín Fierro, V., 2479-2480), como también en su pathos ("es un telar de desdichas / cada gaucho que usté ve", Martín Fierro, V., 2309-2310); es decir, en su discurso y en su metadiscurso; pero también son figuras que se han deslizado hacia la fundación de la poética de Leónidas Lamborghini:

Ya estaba [yo de chico] queriendo agarrar el telar, como un hobby, o la banqueta. Pero observaba ciertas cosas, me di cuenta de ciertas fallas técnicas. Yo le decía al viejo. Pero me precio de haberme dado cuenta el porqué de las varaduras... En el telar vos

17 "Vivir sin esperanza en el deseo de encontrar una voz" (Leónidas Lamborghini, en Monteagudo).

Revista Iberoamericana, Vol. LXXXI, Núm. 250, Enero-Marzo 2015, 333-350 ISSN 0034-9631 (Impreso) 
ponés la tela tejida en azul en el tribunal de las telas en crudo y entonces ves que en una parte el color azul agarró más que en otras... (entrevista de Llach). ${ }^{18}$

Oh Máquina de los Recuerdos

y esta música traqueteante

renace, que aún vive, que aún persiste

de los batanes. ${ }^{19}$

Gran Cuarto de los zurcidos

bajo el tribunal de las telas en crudo

en otoño nací.

¿Mi destino estaba sellado?

(“Las patas en las fuentes", 2008, 169 y ss.)

La reescritura es uno de los procedimientos fundamentales de la poética de Lamborghini, si no es el más importante y distintivo. Este procedimiento se ha ocupado con insistencia del universo discursivo popular. "Las patas en las fuentes" [1965] y "Eva perón en la hoguera" [en Partitas, 1972] son obras que reinventan a los personajes Sargento Cruz, Martín Fierro y Eva Perón, y reescriben sus discursos (los cantos del poema de Hernández y la autobiografía del Evita en La razón de mi vida). El concepto de reescribir no es equivalente al de "glosar" (explicación o comentario); más bien se trata de la reelaboración ("Las patas...") o reensamblaje ("Eva Perón en la hoguera") de un texto/tejido origen (fuente) que se vierte en un texto/tejido destino (reescritura). Estamos ante un proyecto que construye su obra con voces/madejas ajenas, que comienza en sus poemarios tempranos (los personajes El saboteador y El solicitante son las máscaras del Sargento Cruz y Martín Fierro) y se cierra como proyecto creativo (como poética) con Odiseo confinado (1992), en el que tematiza el fracaso de la reescritura como procedimiento y como forma conflictiva (payada, finta) de relacionarse con la tradición.

Reescribir un texto es un acto de intrusión, mutación y permutación de los elementos constitutivos de una fuente. Puede reescribirse 1) con las mismas palabras del original ó 2) en otra selección léxica y/u otra sintaxis. En la primera modalidad, "reensamblaje" con las mismas palabras del texto origen, "Eva Perón en la hoguera" y "Villas" son casos modelo. Se trata de una reescritura "de segundo grado" (llamada por el autor "reescritura

\footnotetext{
18 Juego con el lenguaje (sentido lúdico) y juego del lenguaje (como las piezas de un mecanismo que hacen juego, sentido técnico): “¿Y dónde no agarró tanto? En las varaduras. Es una distensión del tejido donde la trama está más abierta, entre trama y trama hay una abertura así y normalmente tiene que haber esto. Y un día voy por atrás del telar y tiene un engranaje que va soltando el hilo para que luego el batán y la trama hagan con los hilos la tela, y yo veía que el gatillo del engranaje iba de a un diente, trac, trac, y en una de esas saltaba, iba de a dos dientes. Ahí se producía la falla...”.

19 Máquina generalmente hidráulica, compuesta de gruesos mazos de madera, movidos por un eje, para golpear, desengrasar y enfurtir los paños (DRAE).
}

Revista Iberoamericana, Vol. LXXXI, Núm. 250, Enero-Marzo 2015, 333-350 ISSN 0034-9631 (Impreso) ISSN 2154-4794 (Electrónico) 
intratextual"). En el segundo modo -como ejemplo sirva "Las patas en las fuentes"-, se trata de reescrituras "de primer grado", o "reelaboraciones". En palabras del propio Lamborghini: "en mis reescrituras hay una intrusión violenta en el interior del texto del modelo, de su materia verbal. El modelo es reescrito con sus propias palabras o en otra combinatoria y otra sintaxis" (Lamborghini, entrevista de Zapata). Valgan como ejemplo de reescritura-reelaboración estas dos tiradas en espejo: El gaucho Martín Fierro (texto origen) y "Las patas..." (texto destino).

Aquí me pongo a cantar Al compás de la vigüela,

Pido a los Santos del Cielo

Que ayuden mi pensamiento; Les pido en este momento Que voy a cantar mi historia Me refresquen la memoria Y aclaren mi entendimiento.
Me detengo un momento por averiguación de antecedentes

vena mía poética susúrrame contracto planteo, combinación y remate. (...)

(El gaucho Martín Fierro)

(“Las patas en las fuentes")

El extenso poema "Las patas en las fuentes" es fundamental para comprender las distintas formas de experimentación poética y crítica cuyo objeto es la gauchesca. Primero y principal, el texto está estructurado en dos partes (como las dos partes del poema hernandiano: El Gaucho Martín Fierro [1872] y La Vuelta de Martín Fierro [1879]) y está articulado con una forma enunciativa que en la tradición argentina ha sido utilizado casi exclusivamente, desde sus orígenes, por la gauchesca: el diálogo. Entre dos personajes, El Solicitante Descolocado y El Saboteador Arrepentido: el primero solicita trabajo, "laburo" ("Desempleado/buscando el mango hasta más no poder", 309-310), y en la Segunda Parte (422 y ss.), poder. El Saboteador es un obrero textil convertido en gerente, en patrón (como el Sargento Cruz se arrepiente de su rol de policía):

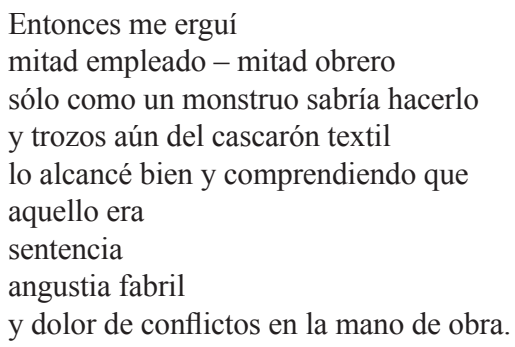




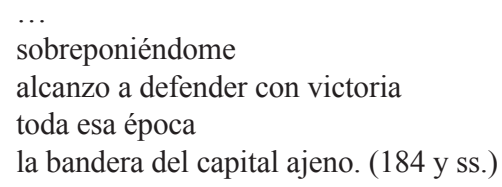

Lamborghini reelabora con total libertad y sin embargo con velada fidelidad los episodios del poema de Hernández: entre otros episodios, nos encontramos con una recreación de la vida en las tolderías (MF, V., 375 y ss.) y con su estado de beatitud, pero en clave materialista ("jubilación y vacaciones pagas", 403 y ss.); nos encontramos con un cierre a dos voces, como Martín Fierro, y también hallamos un enunciatario "público", o círculo del fogón: "El solicitante y el Saboteador del público/se despiden" // “y aquí me despido yo,/ que referí ansí a mi modo..." (MF, 2313-2314).

La segunda parte (también más extensa que la primera, como en MF), tan cercana a la experiencia de la proscripción peronista como a la reelaboración fiel de Martín Fierro nos muestra a un joven (616-617) que bien podría ser uno de los hijos de Fierro (cantos XII y ss.); (a) una imagen que reelabora el regreso del desierto (690 y ss.); (b) la escena de la golpiza brutal del indio a la cautiva que gatilla la huida de Fierro de las tolderías (700 y ss.); y (c) hasta la muerte de Cruz/Saboteador (1905 y ss.).

(a)

\section{Martín Fierro}

Viene uno como dormido

cuando vuelve del desierto; (MF 7-8)

El saboteador arrepentido

y ahora si no tomo

placidom

soy muy capaz de reventar

porque lo reconozco

desde el día que tomé la droga

el sol

amortiguó sus golpes

(b)

\section{Martín Fierro}

¡Me horrorisa todavía

el cuadro que descubrí!

Era una infeliz muger

que estaba de sangre llena,

y como una Madalena

lloraba con toda gana;

Revista Iberoamericana, Vol. LXXXI, Núm. 250, Enero-Marzo 2015, 333-350 
conocí que era cristiana y esto me dió mayor pena.

Cauteloso me acerqué a un indio que estaba al lao, porque el pampa es desconfiao siempre de todo cristiano, $\mathrm{y}$ vi que tenia en la mano el rebenque ensangrentao. (VII)

El saboteador arrepentido en plena calle sorprendiendo la escena de la tipa que eras una palomita grita él $\mathrm{y}$ ahora sos una perra traidora

entonces puta puta

le dice en plena calle él... ()

(c)

\section{Martín Fierro}

Se le pasmó la virgüela, y el pobre estaba en un grito; me recomendó un hijito que en su pago habia dejado. "Ha quedado abandonado", me dijo, aquel pobrecito. (VI)

Aquel bravo compañero en mis brazos espiró; hombre que tanto sirvió, varon que fue tan prudente, por humano y por valiente en el desierto murió. (VII)

El solicitante descolocado Entonces vi al saboteador arrepentido

llevaba una bomba casera entre sus manos

"y ya no estoy arrepentido" 
me dice

cuando a los pocos pasos

la bomba estalló contra su vientre y aún así reventado

llama

y yo acerco mi oído tenso a su boca

"la redención por la lucha"

me dice

"la insurrección es un arte

es un arte"

y así

expiró entre mis brazos.

\section{BREVES CONSIDERACIONES FINALES}

En este escrito, la relectura de la crítica y la historiografía de la literatura gauchesca -constituidas por interpretaciones y valoraciones de diversas inscripciones históricasfue conducida por la reflexión sobre los dispositivos de esta ficción cultural particular, e iluminada por los procedimientos poéticos y críticos (y poético-críticos) de Leónidas Lamborghini. Hemos revisado el archivo de la gauchesca, buscando hacer ondas sobre su superficie homogeneizada, buscando arrugar la tersura de todo discurso ordenador. Desmontar, modestamente, la constitución de una ficción cultural de la literatura argentina.

Según el sistema constructivo de la reescritura utilizado por Lamborghini, en principio, no hay texto que no pueda ser reescrito, como no hay paño que no pueda ser deshilachado y destejido. Pero acaso lo más interesante que Leónidas Lamborghini ha propuesto es la posibilidad de reescribir una tradición. En este sentido, su experimentación con la gauchesca -que transcurre al menos entre 1956 y 1990- genera en el canon literario una serie de corrimientos, reevaluaciones y desplazamientos que termina contaminando al canon crítico. 


\section{BiBLIOGRAFÍA}

Becco, Horacio. Antología de la poesía gauchesca. Bilbao: Aguilar, 1972.

De la Campa, Román. "América Latina y sus nuevos cartógrafos: discurso poscolonial, diásporas intelectuales y miradas fornterizas”. Revista Iberoamericana LXII/176177 (1996).

“Norteamérica y su mundo latino". Revista Iberoamericana LXVIII/200 (2002): 879-895.

Díaz Quiñones, Arcadio. La memoria rota. Puerto Rico: Huracán, 1993.

Gutiérrez, Juan María. La literatura de Mayo y otras páginas críticas. Buenos Aires: Centro Editor de América Latina, 1979.

Hernández, José. El gaucho Martín Fierro. 1879. España: Losada, 2000.

Lafforgue, Jorge. "José Hernández: la integridad nacional". Explicar la Argentina. Buenos Aires: Taurus, 2009.

Lamborghini, Leónidas. El solicitante descolocado. Buenos Aires: Paradiso, 2008 Mezcolanza. Buenos Aires: Emecé, 2010

Llach, Santiago. Tengo una jubilación mínima y estoy acá. Entrevista a Leónidas Lamborghini. 28 marzo 2011: El interpretador. Literatura, arte y pensamiento. Web. 25 octubre 2014.

Libertella, Héctor. La librería argentina. Córdoba: Alción, 2003.

Lois, Élida. "Cómo se escribió el Martín Fierro". Historia Crítica de la Literatura Argentina. 2: La lucha de los lenguajes, 193-224. Buenos Aires: Emecé, 2003.

Mignolo, Walter. "Después de América "Latina", una vez más". La idea de América Latina. Barcelona: Gedisa, 2007.

Monteagudo, Andrés y Esteban Bertola. El solicitante descolocado. Encuentros con Leónidas Lamborghini. Video. Web. 29 octubre 2014.

Rama, Ángel. "El sistema literario de la poesía gauchesca”. Poesía gauchesca. J. B. Rivera, ed. Caracas: Bibioteca Ayacucho, 1977.

Los gauchipolíticos rioplatenses. Buenos Aires: CEAL, 1994.

Rivera, Jorge (comp.). Poesía gauchesca. Caracas: Biblioteca Ayacucho, 1977.

Rojas, Ricardo. Historia de la literatura argentina. Los gauchescos (Vol. 1 y 2). Buenos Aires: Kraft, 1957.

Romano Sued, Susana. "Malestar en la Estética. Kant, el imperativo ético contra los críticos seriales”. Abril de 2011. Expoesía. Web. 12 noviembre 2014.

Williams, Raymond. Marxismo y literatura. Barcelona: Península, 1997.

Zapata, M. Á. "Entre la reescritura y la parodia". Abril de 2011. El jornaldepoesía.

Web. 1 diciembre 2014.

Revista Iberoamericana, Vol. LXXXI, Núm. 250, Enero-Marzo 2015, 333-350 ISSN 0034-9631 (Impreso)

ISSN 2154-4794 (Electrónico) 